\title{
Lack of leptin activity in blood samples of Adélie penguin and bar-tailed godwit
}

\author{
Sara Yosefi, Gideon Hen, Charles I Rosenblum ${ }^{1}$, David J Cerasale², Michaël Beaulieu², \\ Francois Criscuolo ${ }^{3}$ and Miriam Friedman-Einat \\ Department of Poultry and Aquaculture Sciences, Institute of Animal Science, Agricultural Research Organization (ARO), Volcani Center, \\ PO Box 6, Bet Dagan 50250, Israel \\ ${ }^{1}$ Merck Research Laboratories, Department of Metabolic Disorders-Diabetes, Rahway, New Jersey 07065, USA \\ ${ }^{2}$ Department of Ecology and Evolutionary Biology, Cornell University, Ithaca, New York 14853, USA \\ ${ }^{3}$ Department of Ecology, Physiology and Ethology, Institut Pluridisciplinaire Hubert Curien, CNRS-UdS, 23 Becquerel, 67087 Strasbourg, France \\ (Correspondence should be addressed to M Friedman-Einat; Email: einat@agri.huji.ac.il)
}

\begin{abstract}
Unsuccessful attempts to identify the leptin gene in birds are well documented, despite the characterization of its receptor (LEPR). Since leptin and LEPR have poor sequence conservation among vertebrates, we speculated that a functional assay should represent the best way to detect leptin in birds. Using a leptin bioassay that is based on activation of the chicken LEPR in cultured cells, blood samples from wild birds with extreme seasonal variation in voluntary food intake and fat deposition (Adélie penguins and bar-tailed godwits) were tested for leptin activity. In these experiments, blood samples collected during the
\end{abstract}

pre-incubation and the chick-rearing periods of Adélie penguins, and during the migratory flight and refueling stages of bar-tailed godwits, were found to contain no detectable leptin activity, while the sensitivity of the assay to activation by human blood samples from donor subjects representing a variety of body mass indices and fat contents was clearly demonstrated. These results suggest that in birds, an alternative control mechanism to that of mammals operates in the communication between the body fat tissues and the central control on energy homeostasis.

Journal of Endocrinology (2010) 207, 113-122

\section{Introduction}

In mammals, the satiety hormone leptin (Zhang et al. 1994) is secreted primarily by the fat tissue and has proven to be a key regulator of energy metabolism (Friedman 2002, Farooqi \& O'Rahilly 2009). Leptin signals the amount of fat stores to the hypothalamus and peripheral tissues, which then modulate their activity according to energy status. The more recent identification of leptin and leptin receptor (LEPR) in non-mammalian vertebrates, such as fish (Johnson et al. 2000, Huising et al. 2006, Kurokawa et al. 2008, Yacobovitz et al. 2008, Kurokawa \& Murashita 2009) and amphibians (Boswell et al. 2006, Crespi \& Denver 2006), and the identification of LEPR in chickens (CLEPR) and in turkeys by us and others (Horev et al. 2000, Ohkubo et al. 2000, Richards \& Poch 2003, Liu et al. 2007) strongly suggest the presence of leptin in birds. Expression of the CLEPR in brain and other tissues was demonstrated at both the mRNA (Horev et al. 2000, Ohkubo et al. 2000, Richards \& Poch 2003, Dridi et al. 2005b, Liu et al. 2007, Adachi et al. 2008, Byerly et al. 2009, Yuan et al. 2009) and the protein (Ohkubo et al. 2007) levels. We previously mapped the CLEPR to a chromosomal site syntenic to that in humans (Dunn et al. 2000). In addition, we showed that when introduced into HEK-293 cells together with a signal transducers and activators of transcription 3 (STAT3)-derived reporter gene, CLEPR specifically activates the reporter gene in response to leptin (Hen et al. 2008). Specific STAT3 phosphorylation and activation of the Janus kinase (JAK)-STAT pathway by CLEPR in vitro, similar to the signal transduction pathway characterized in mammals, were demonstrated in several cell culture systems (Adachi et al. 2008). In addition, the recombinant predicted leptin-binding domain of CLEPR was shown to specifically bind leptins of several origins in vitro (Niv-Spector et al. 2005).

Altogether, these demonstrations of conservation of CLEPR with respect to its structure, chromosomal position, expression pattern and biological activity (Dunn et al. 2000, Horev et al. 2000, Ohkubo et al. 2000, Richards \& Poch 2003, Niv-Spector et al. 2005, Liu et al. 2007, Adachi et al. 2008, Hen et al. 2008) could be considered as an indication of its function in vivo. However, the CLEPR ligand has not yet been found (Friedman-Einat et al. 1999, Dunn et al. 2001, Amills et al. 2003, Sharp et al. 2008, Pitel et al. 2009). In addition, despite the nearly complete sequencing of the chicken genome 
(Burt 2006) and extensive sequencing of chicken fat expressed sequence tags (ESTs) (Cogburn et al. 2003), no sequence similarity to leptin has been identified, nor has any similarity been found at the protein level (Sharp et al. 2008).

Our hypothesis was that since leptin is among the class-I helical cytokines with the poorest sequence conservation in vertebrates (Huising et al. 2006), a functional assay might be a more appropriate way of detecting it, compared with assays depending on sequence similarity. In a previous report (Hen et al. 2008), we described a chicken leptin bioassay in cultured HEK-293 cells based on the exogenous expression of CLEPR and a luciferase reporter gene. The sensitivity of this assay system to various heterologous leptins of Xenopus and mammalian origin was demonstrated, but we failed to detect specific leptin activity in blood samples from commercial chicken strains with lean or fat phenotypes (Hen et al. 2008). One of the hypotheses to explain the absence of leptin in these commercial chicken strains was that it had disappeared in the course of intensive genetic breeding toward high production yields.

Therefore, the presently described study focused on detecting leptin activity in blood samples of wild birds. Adélie penguin (Pygoscelis adeliae) and the bar-tailed godwit (Limosa lapponica) are very different birds, but both transiently accumulate exceptionally high amounts of fat, to over $20-30 \%$ of their body weight (BW), which is followed by extreme voluntary periods of food withdrawal (incubation and migration respectively). The hypothesis was that if leptin is the satiety hormone in birds, it should have a dominant role in the extreme seasonal differences in appetite and fat accumulation in these birds.

The breeding cycle of the Adélie penguin comprises four phases: i) the courtship from mid-October to early November; ii) the incubation of one or two eggs for 30-36 days; iii) the guard stage (from mid-December to mid-January) when both parents alternate between foraging at sea and chick attendance at the nest, and iv) the crèche stage (from mid-January to mid-February), when both parents can forage at the same time leaving the chick(s) alone in the colony. By using body mass and total body water content being measured by isotope dilution, Chappell et al. (1993) determined the body composition of Adélie penguins and precisely described how body mass, depot fat, and lean tissue simultaneously change along the breeding cycle. When they arrive on the colony to breed at the beginning of the austral summer, Adélie penguins are heavy (males: $4 \cdot 5-5 \cdot 5 \mathrm{~kg}$ and females: $4 \cdot 0-4 \cdot 5 \mathrm{~kg}$ ), and depot fat represents $20-30 \%$ of the penguins' body mass. During the incubation fast, penguins' body mass decreases mainly through fat loss (and to a lesser extent through lean tissue loss). Consequently, depot fat decreases sharply during the incubation stage but remains low and stable (7-10\%) from the end of the incubation through the chick-rearing period in both males and females (Chappell et al. 1993).

The bar-tailed godwit is a migratory bird that performs the longest known non-stop migratory flight $(11500 \mathrm{~km}$ from Alaska to New Zealand (McCaffery \& Gill 2001). Here, we studied a subspecies of bar-tailed godwits (L. lapponica taymyrensis) during spring migration from wintering areas in West Africa to breeding grounds in northern Russia (ca. $9000 \mathrm{~km}$ ). Godwits perform this migration in two non-stop flights of 2-3 days each (ca. $4500 \mathrm{~km}$ ), stopping on the coast of the Wadden Sea in Germany, Denmark, and The Netherlands to refuel (Piersma \& Jukema 1990). On arrival in the coast of the Wadden Sea, godwits are emaciated and are in a state of extreme fasting (see Landys-Ciannelli et al. (2002)). During their month-long stopover, godwits double their body mass and deposit large amounts of fat (i.e. over 30\% of body mass), which constitute the main fuel for subsequent migratory flights (Landys et al. 2005) to Russia.

In this report, blood samples collected during the pre-incubation and guard stages of Adélie penguins, and the migratory flight and refueling stages of bar-tailed godwits were compared with human blood samples collected from donor subjects representing a variety of body mass indices (BMIs) and fat contents using a leptin bioassay that is based on activation of the CLEPR.

\section{Materials and Methods}

\section{Cytokines}

Human leptin was kindly donated by Prof. Arieh Gertler (The Hebrew University, Rehovot, Israel). Interferon- $\alpha$ (IFN- $\alpha$ ) was a kind gift from Dr Daniela Novic and Dr Meacham Rubinstein at the Weizmann Institute of Science, Rehovot, Israel.

\section{Human blood sampling}

Human blood samples were collected from volunteers by a registered nurse. The samples were divided into two aliquots for plasma and serum preparation. For serum preparation, the blood samples were left at room temperature for a few hours and then kept in the refrigerator overnight. For plasma preparation, the samples were transferred to heparinized tube in ice. After separation of serum/plasma at $1500 \mathrm{~g}$ centrifugation, each sample was divided into two aliquots: one was kept at $-20{ }^{\circ} \mathrm{C}$ and the other was dried by lyophilization. Lyophilized samples were restored to their original volumes with double-distilled water.

\section{Adélie penguin seasonal cycle and blood sampling}

Adélie penguins breed all around Antarctica from mid-October to mid-February. For this study, penguins were captured in the French station Dumont d'Urville $\left(66^{\circ} 40^{\prime} \mathrm{S}\right.$, $\left.140^{\circ} 00^{\prime} \mathrm{E}\right)$ in the austral summer 2007-2008. Blood was collected from the wing vein with a heparinized syringe during the pre-incubation stage from nine females and seven males, and 40-45 days after egg-laying during the guard stage from eight females and eight males. Sex determination was 
carried out by using a combination of parameters including cloacal inspection before egg-laying, copulatory behavior, and incubation routine (Taylor 1962, Kerry et al. 1993). After centrifugation, plasma and red blood cells were separated and stored at $-20^{\circ} \mathrm{C}$. After blood collection, each penguin was weighed with an electronic balance (Ohaus Corporation, Nänikon, Switzerland, $\pm 2 \mathrm{~g}$ ). As expected, males were heavier than females (general linear model (GLM): $F_{1,28}=16 \cdot 58$, $P<0 \cdot 001$ ), and penguins were about $9 \%$ heavier before the incubation than during the guard stage $(4 \cdot 81 \pm 0.55 \mathrm{~kg}$ and $4 \cdot 39 \pm 0 \cdot 44$ (mean \pm s.D.) respectively; GLM: $F_{1,28}=13 \cdot 12$, $P<0.001)$; this percentage corresponds to the difference in body mass reported by Chappell et al. (1993) between these two breeding stages. Although the body mass difference between the pre-incubation and guard stages tended to be higher in males than in females, this was not significant (GLM: $F_{1,28}=3 \cdot 40, P=0 \cdot 08$ ).

\section{Bar-tailed godwit migratory route and blood sampling}

Bar-tailed godwit blood samples were collected from birds at two sites. At the first site, 'arriving birds' were lured to land using song playback and decoys in the dunes near Castricum, The Netherlands $\left(52^{\circ} 32^{\prime} \mathrm{N}, 04^{\circ} 37^{\prime} \mathrm{E}\right), 60 \mathrm{~km}$ from their established stopover site in the Wadden Sea. At the second site, in Terschelling, The Netherlands $\left(53^{\circ} 39^{\prime} \mathrm{N}, 0^{\circ} 32^{\prime} \mathrm{E}\right)$, birds were captured during the middle of their refueling period as described before (Landys et al. 2005). After capture, body mass was measured on a digital balance $( \pm 0 \cdot 1 \mathrm{~g})$, and wing length was measured with a wing ruler $( \pm 0.5 \mathrm{~mm})$. Whole blood was collected by brachial vein puncture. Plasma was separated by centrifugation at $1500 \mathrm{~g}$, flash frozen in liquid nitrogen dry shippers, stored at $-80{ }^{\circ} \mathrm{C}$, and lyophilized.

\section{Leptin activity}

Leptin activity was measured using a bioassay (Hen et al. 2008) consisting of HEK-293 cells expressing exogenous full-length CLEPR CDNA and a luciferase reporter gene under the control of a STAT3-responsive element, as described previously (Hen et al. 2008). Briefly, test and control cultures, harboring both CLEPR and reporter genes or the reporter gene only, respectively, were plated in 48-well tissue culture plates (Nunc, Danyel Biotech, Rehovot, Israel) at a concentration of $2 \times 10^{5}$ cells per well in a final volume of $200 \mu \mathrm{l}$. The following day, medium in each well was replaced with $150 \mu \mathrm{l}$ DMEM (Gibco/BRL) or with medium containing purified proteins (leptin or IFN- $\alpha$ ), or with medium containing $15 \mu \mathrm{l}$ plasma samples for $4 \mathrm{~h}$. Medium was then aspirated, and the cells were lysed by adding $100 \mu \mathrm{l}$ Promega cell lysis reagent. A $40 \mu \mathrm{l}$ aliquot of each cell lysate was mixed with $40 \mu \mathrm{l}$ Promega luciferase assay agent. Luciferase activity was measured using the TD20e luminometer (Turner Design, Mountain View, CA, USA).
IFN- $\alpha$ activates the STAT3-responsive element similar to leptin. However, unlike leptin, IFN- $\alpha$ operates through an endogenous receptor. Therefore, IFN- $\alpha$ was used to demonstrate the presence of the inducible reporter construct in the control cell line. The response to IFN- $\alpha$ is expected to be similar in both the control and the CLEPR cell lines. However, on repeated freezing and thawing cycles, the control cells have acquired a higher sensitivity to IFN- $\alpha$.

\section{Estimation of fat contents}

Fat contents in the human donors were estimated according to BMI values, taking into account age, gender (Jackson et al. 2002), and physical activity (Sempolska \& Stupnicki 2007), and using the Linear Software at http://www.linear-software. com/online.html.

For Adélie penguins, fat content estimation was based on previous report (Chappell et al. 1993) using a detailed isotope dilution approach. In our study, body mass of the courtship (males: $5 \cdot 27 \pm 0 \cdot 37 \mathrm{~kg}$; females: $4 \cdot 46 \pm 0 \cdot 38 \mathrm{~kg}$ ) tightly corresponded to the body mass of penguins at arrival (Chappell et al. 1993 ; males: $5 \cdot 10 \pm 0 \cdot 27 \mathrm{~kg}$ and females: $4 \cdot 53 \pm 0 \cdot 35 \mathrm{~kg}$ ), which were found to contain 28 and $22 \%$ body fat in males and females respectively. Similarly, fat content during the guard stage was estimated to be 10 and $8 \%$ of the body mass of males and females respectively (Chappell et al. 1993).

Body fat content of bar-tailed godwit was estimated based on formulas described previously (Piersma \& Jukema 1990) correlating body fat mass, body mass, and wing length of bar-tailed godwit. The calculated values of fat mass for the birds presented here are within the range of fat mass from studies that have directly measured body fat content (Landys-Ciannelli et al. 2002).

\section{Statistical analysis}

Content data were analyzed by one-way ANOVA, Student's $t$-test, and Tukey-Kramer test. The analyses were performed using JMP 5.1 software (SAS Institute, Cary, NC, USA) at a significance level of $P \leq 0 \cdot 05$.

\section{Results}

Analysis of leptin activity in blood samples from Adélie penguins

A bioassay, developed previously in our laboratory for the detection of leptin activity through activation of CLEPR in cultured cells (Hen et al. 2008), was used to monitor leptin activity in the plasma samples of Adélie penguins (Fig. 1). Although the human plasma sample, used as a positive control, significantly and specifically activated luciferase activity in the CLEPR-expressing cells, but not in the control cells, no such activity could be detected in the plasma samples from male and female penguins at the pre-incubation and guard stages (Fig. 1). 


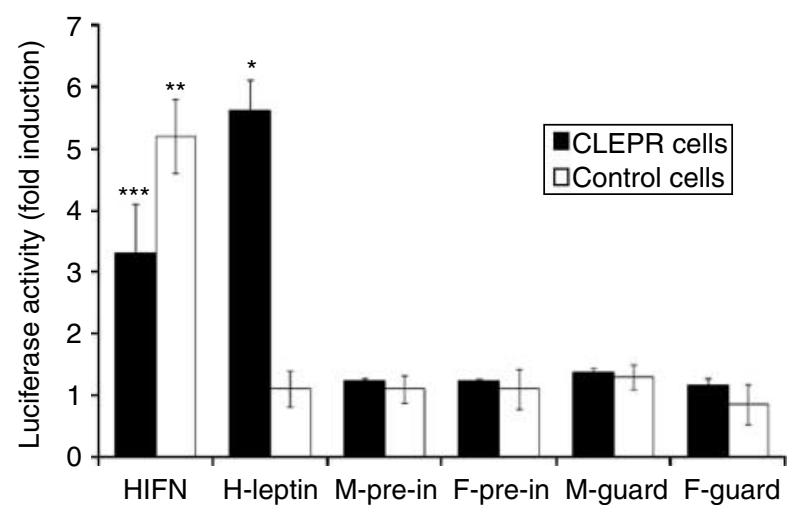

Figure 1 Absence of leptin activity in plasma samples from Adélie penguins. Plasma samples collected from Adélie penguins at the indicated seasonal periods were incubated with CLEPR-transfected cells and control cell lines, and induction of the reporter gene luciferase was measured as detailed in 'Materials and Methods' section. Recombinant human leptin (final concentration $30 \mathrm{ng} / \mathrm{ml}$ ) and IFN $-\alpha(30 \mathrm{U} / \mathrm{ml})$ were used as controls. IFN- $\alpha$ was used to demonstrate the presence of the inducible luciferase activity in the control cell line as detailed in 'Materials and Methods' section. Data are expressed as fold stimulation over culture medium alone and are means \pm S.E.M. from seven to nine samples of the female $(F)$ and male $(M)$ at pre-incubation (pre-in) and guard stages, performed in duplicates; and from three independent assays for the leptin and IFN- $\alpha$. Except for the recombinant human leptin and IFN- $\alpha$, no other treatment exhibited significant induction at $P \leq 0 \cdot 05$. $* P<0.002$ compared with value for control cells. ${ }^{* *} P>0.02$ compared with the values for control cells of the other treatments. *** $P>0.05$ compared with the CLEPR cells treated with the bird's sample.

\section{Analysis of leptin activity in samples from bar-tailed godwits}

Blood samples from migratory flight and refueling stages of bar-tailed godwits were tested for leptin activity, and as can be observed in Fig. 2, no leptin-like activity was detected in the plasma samples collected at either seasonal stage. The same results were obtained when the bioassay was performed at $20 \%$ instead of $10 \%$ plasma concentration (not shown).

\section{Activation of CLEPR by human blood samples}

Leptin activity in the plasma samples from humans with variety of BMI values was tested in the CLEPR bioassay. As shown in Fig. 3, specific activation of CLEPR was observed with all of the samples, including those from donors with low BMI values. The relatively high-fold induction values obtained for the recombinant leptin and for the plasma samples from subjects with BMIs 32 and 23.5 are within the plateau phase of bioassay. To get the expected linear correlation between the leptin activity and the BMI values, each sample had to be repeated at several dilutions as described earlier (Friedman-Einat et al. 2003). However, more important is the finding that the plasma samples obtained from subjects with relatively low BMI values significantly activated CLEPR signal transduction.
In this assay, possible sensitivity to plasma lyophilization, which was used to preserve the birds' plasma samples, was found to have no effect on leptin activity. These control studies were repeated several times with several blood samples (representative results are shown in Fig. 3). The use of serum instead of plasma prepared from the same blood sample had no effect on leptin activity (data not shown).

To estimate the relevance of the human controls to the bird analyses, estimated proportions of body fat were used, based on the constituent correlation characterized in mammals between body fat and circulating leptin activity (Levine et al. 1999, Sagawa et al. 2002, Staiger et al. 2003, Kempf et al. 2006, Smith et al. 2006, Friedman 2009). As shown in Table 1, the estimated fat content of some of the penguins and bar-tailed godwits was within the range of the human samples that induced luciferase activity in the bioassay. The higher estimated fat stores in the BMI of female compared with the BMI 22 of male are compatible with the higher leptin activity in the corresponding blood samples as shown in Fig. 3.

\section{Analysis of possible leptin inhibitory activity in the blood samples}

To test for the possibility of leptin inhibitory activity in the birds' blood samples, leptin spike-in experiment was performed (Fig. 4). As demonstrated in Fig. 4, CLEPRexpressing cells responded to incubation with recombinant human leptin, regardless of the presence of penguin plasma. The recombinant human leptin similarly showed an additive effect when mixed with a human blood sample. This result suggests that there is no leptin-inhibiting activity in the penguin blood samples, which would inhibit the CLEPR activation in the bioassay.

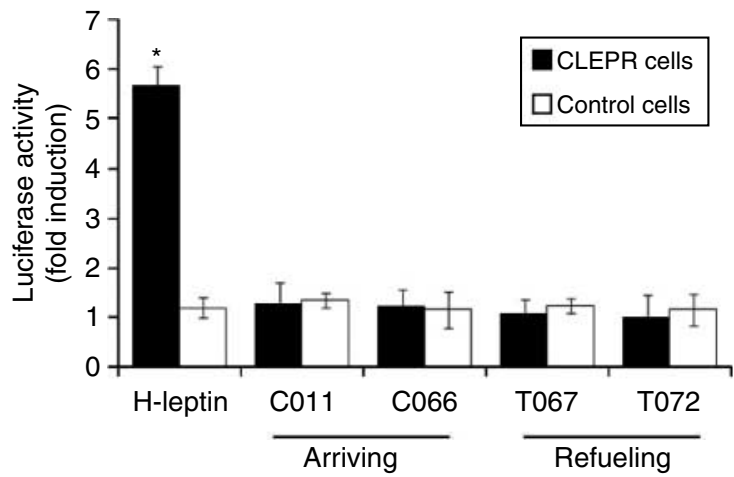

Figure 2 Absence of leptin activity in plasma samples from bartailed godwit birds. Plasma samples were collected from bar-tailed godwit birds at the indicated seasonal periods. Samples were incubated with CLEPR-transfected cells and control cells as described in Fig. 1. Data are expressed as fold stimulation of the reporter gene luciferase over culture medium alone and are means \pm s.D. from two independent experiments, performed in duplicate. Except for the signal obtained with recombinant human leptin (final concentration $30 \mathrm{ng} / \mathrm{ml}$ ), no other treatment exhibited significant induction at $P \leq 0 \cdot 05 .{ }^{*} P<0 \cdot 002$ compared with value for control cells. 


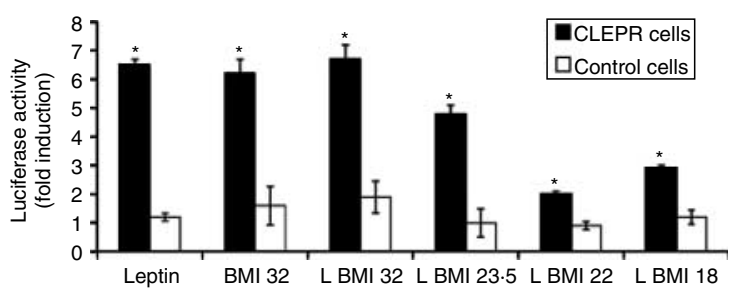

Figure 3 Leptin activity in human blood samples. Stimulation of luciferase activity in CLEPR and control cell lines by recombinant human $(\mathrm{H})$ leptin $(30 \mathrm{ng} / \mathrm{ml})$ and by plasma samples from human subjects with different BMIs (L, lyophilized plasma sample). The assay was performed as described in Fig. 1. The values obtained for the recombinant leptin and for the BMIs 32 and 23.5 are within the plateau phase of bioassay. Data are expressed as fold stimulation of the reporter gene luciferase over culture medium alone and are means \pm s.D. from two independent experiments, performed in duplicates. ${ }^{*} P<0 \cdot 05$ compared with value for control cells.

\section{Discussion}

Using a chicken leptin bioassay, which is based on the expression of CLEPR in cultured cells, we found for the first time the lack of leptin bioactivity in the blood samples of wild birds with extreme seasonal variation in voluntary food intake and fat deposition. These results were unexpected due to the characterization of the LEPR in chickens and turkeys (Horev et al. 2000, Ohkubo et al. 2000, Richards \& Poch 2003), and the demonstration that these receptors have retained their leptin-binding and signal transduction activities (Niv-Spector et al. 2005, Adachi et al. 2008, Hen et al. 2008).

The use of rare blood samples obtained from Adélie penguins and bar-tailed godwits provided a crucial indication that, in birds, signaling the amount of fat stores is not mediated by leptin. This study strongly suggests that the previously reported lack of leptin activity in chickens (Hen et al. 2008) is not due to intensive genetic breeding of commercial chicken strains or to their relative leanness, but is also characteristic of wild birds in their natural habitat exhibiting voluntary seasonal changes in appetite and fat deposition.

Despite relatively low predicted amino acid sequence similarity (about 60\%) between CLEPR and the mammalian orthologs (Horev et al. 2000, Ohkubo et al. 2000), a high degree of cross-activation of CLEPR by mammalian leptins has been previously reported by us and others (Adachi et al. 2008, Hen et al. 2008). The cross-species binding of CLEPR has been demonstrated both in modified cell cultures expressing exogenous CLEPR cDNA (Adachi et al. 2008, Hen et al. 2008) and by surface plasmon resonance assay using the recombinant leptin-binding domain of CLEPR (Niv-Spector et al. 2005). These results are compatible with the high similarity in predicted tertiary structure between the mammalian leptin and the highly divergent Xenopus leptin (Crespi \& Denver 2006).

Physiological concentrations of circulating leptin in mammals range from about 3 to $80 \mathrm{ng} / \mathrm{ml}$ (Tomimatsu et al.
1997, Farooqi et al. 2001, Friedman-Einat et al. 2003, Nkrumah et al. 2007). We previously demonstrated that both the CLEPR cells described herein and human LEPRexpressing cells described in previous reports (Rosenblum et al. 1998, Marikovsky et al. 2002, Friedman-Einat et al. 2003, Hen et al. 2008) are sensitive to this range of leptin concentrations. The activation of CLEPR by human samples with various BMI values was expected, taking into account that a direct linear correlation between BMI values and circulating leptin levels is observed at the population level (Farooqi et al. 2001). Nevertheless, it is important to note that the CLEPR in our bioassay responded to incubation with blood samples from human donors with various BMI values including values below 25, which are indicative of normal $\mathrm{BW}$ and relatively low fattening. The comparison between the humans and birds used in this study was based on the estimations of their fat deposition. It is logical to assume that if circulating leptin levels in the birds signaled the amount of fat stores to the brain and some peripheral tissues in a manner similar to that in mammals, these leptin levels would be detected in the CLEPR-based bioassay.

The observed absence of leptin degradation or inhibiting activity in the birds' blood samples demonstrated here by spike-in experiments is compatible with a previous report showing that the rate of plasma clearance of infused mouse leptin is quite similar in broiler chickens (23 min; McMurtry et al. 2004) and the clearance of endogenous leptin in humans (25 min; Klein et al. 1996). The spike-in experiment described here also indicates that there is no circulating activity blocking leptin binding to CLEPR in the bioassay. A hypothetical leptin-blocking activity that is highly specific to a putative bird leptin cannot be excluded by our experiments. But this hypothesis seems unlikely because unless operating only in vitro, this chicken leptin-specific blocking activity would be expected to correspond to the bird's physiological state, allowing leptin signaling in a situation of high-fat content (or possibly other physiological states as discussed below).

Table 1 Estimated fat contents in the blood samples of donors

\section{Stage/BMI and gender Percentage of body fat}

Species
Human

$\begin{array}{lr}\text { BMI 32, F } & 34 \\ \text { BMI 23·5, F } & 26 \\ \text { BMI 22, M } & 18 \\ \text { BMI 18, F } & 21 \\ \text { Courtship, M } & 28 \\ \text { Courtship, F } & 22 \\ \text { Guard, M } & 10 \\ \text { Guard, F } & 8 \\ \text { Refueling T067 } & 20 \\ \text { Refueling T072 } & 12 \\ \text { Arriving C011 } & 3 \\ \text { Arriving C066 } & 3\end{array}$

$M$, male; $F$, female. 


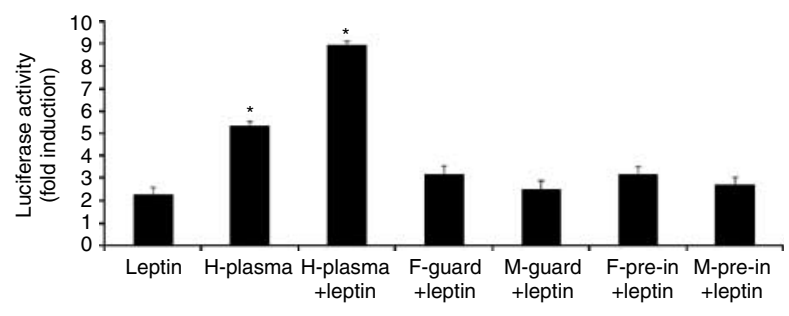

Figure 4 Absence of leptin inhibitory activity in the bird's blood samples. Stimulation of luciferase activity in CLEPR cell line by recombinant human leptin $(10 \mathrm{ng} / \mathrm{ml})$ alone or in combination with plasma samples from female (F-guard) and male (M-guard) at guard stage and from female (F-pre-in) and male (M-pre-in) at preincubation stage. Data are expressed as fold stimulation of the reporter gene luciferase over culture medium alone and are means \pm S.E.M. $(n=3) .{ }^{*} P<0 \cdot 01$ compared with the other leptin treatments. No significant difference was obtained between leptin in the plasma serum compared with leptin alone at $P<0.05$.

In mammals, changes in voluntary food intake and adiposity usually involve changes in leptin sensitivity. In obese humans, except in extremely rare cases, obesity is associated with decreased sensitivity to leptin and increased circulating leptin levels, a phenomenon that has been termed leptin resistance (Frederich et al. 1995, Caro et al. 1996, Ur et al. 1996, Montez et al. 2005). Leptin resistance can be either a pathological state, for example, in diet-induced obesity or an adaptive response allowing shifts in body-energy stores, similar to that occurring in seasonal breeders (Rousseau et al. 2002, Tups et al. 2004, Krol et al. 2007, Zieba et al. 2008, Scarpace \& Zhang 2009, Tups 2009). For example, the Siberian hamster, which has been intensively studied as a model of seasonal mammals, spontaneously reduces its $\mathrm{BW}$ by $\sim 40 \%$ over a 12 -week period in winter (Heldmaier et al. 1982). Circulating leptin levels in Siberian hamsters are very low in winter when appetite is low, and very high when BW and fat deposition are high (Rousseau et al. 2002). Similar observations have been reported in sheep (Miller et al. 2002), woodchucks (Concannon et al. 2001), and root voles (Wang et al. 2006). This phenomenon of BW regulation by transient acquisition of leptin resistance is also observed during pregnancy in humans (Henson \& Castracane 2006, Ladyman et al. 2009). It appears that in the seasonally breeding mammals, leptin sensitivity rather than leptin is the direct factor in seasonal changes in appetite and BW, and circulating leptin levels are directly correlated to the amount of fat stores. This means that leptin levels are high when appetite and fat stores are high, and are low when appetite and fat stores are low. In contrast, in two reports concerning non-mammalian vertebrates, leptin levels have been shown to be inversely correlated to fat accumulation with respect to the seasonal behavior of rainbow trout (Kling et al. 2009) and lizards (Spanovich et al. 2006).

Dramatic seasonal changes in BW and fat stores and the phenomenon of seasonal gonadal regression observed in some seasonally breeding mammals and in lower vertebrates are all common to the Adélie penguins and the bar-tailed godwits. Therefore, elevation of leptin activity in the blood samples of Adélie penguin and bar-tailed godwit was expected in the high-fat seasons (courtship and refueling stages respectively) in case of similarity to mammals or possibly in the low-fat seasons (guard and arriving stages respectively) in case of similarity to rainbow trout and lizards. Our inability to detect leptin activity at any of these stages in these birds suggests that their seasonal control of appetite and fat accumulation is not mediated by circulating leptin or by leptin resistance.

The well-characterized key role of mammalian leptin in the control of energy homeostasis appears to be only partially shared with leptins in non-mammalian vertebrates (Volkoff 2006, Ronnestad et al. 2010). Leptin and LEPR in evolutionarily early vertebrates show relatively low sequence similarity as compared with their mammalian orthologs. For this reason, their genes were only recently identified, and currently, not much is known about their physiological roles. In some evolutionarily lower vertebrates, leptin has been implicated in the regulation of adiposity and reproduction, in addition to the regulation of developmental processes (Peyon et al. 2003, Crespi \& Denver 2006). In addition, characterized pattern of expression, such as dominant expression in the skin and testis in salamander (Boswell et al. 2006) or in the liver in rainbow trout (Pfundt et al. 2009), suggests that the role of leptin in these animals differs from that in mammals. In experiments involving leptin treatment, no effect on food intake or BW could be detected in salmon (Baker et al. 2000), catfish (Silverstein \& Plisetskaya 2000), or green sunfish (Londraville \& Duvall 2002). Although much work is still needed to characterize the role of leptin in these vertebrates, it appears to be less tightly connected to signaling the amount of fat stores than the mammalian leptins.

Previous studies have reported PCR cloning of chicken leptin with extremely high sequence similarity to mouse leptin (Taouis et al. 1998). Reports on the expression of this chicken leptin gene at the mRNA and protein levels were also published (Ashwell et al. 1999a,b, 2001, Richards et al. 1999, 2000, Dridi et al. 2000b, 2005a, 2008, Kochan et al. 2006, Hu et al. 2008, Rao et al. 2009, Yang et al. 2009). This and other leptins were reported to attenuate appetite, fat metabolism, reproduction, and immune response following their application to birds (Denbow et al. 2000, Dridi et al. 2000a, 2005a,b, 2007, Benomar et al. 2003, Lohmus et al. 2003, 2004, 2006, Paczoska-Eliasiewicz et al. 2003, 2006, Cassy et al. 2004, Kuo et al. 2005, Figueiredo et al. 2007, Yang \& Denbow 2007), and to affect proliferation, apoptosis, and secretory activity in cultured chicken ovarian cells (Sirotkin \& Grossmann 2007) and CLEPR expression in cultured chicken hepatoma cells (Cassy et al. 2003). In contrast, immunization against leptin decreased appetite and egg-laying (Yang et al. 2009); moreover, other reports showed no effect of exogenous leptin by i.c.v. injection in chicks (Bungo et al. 1999) and in a chicken model of skeletal bone growth (Mauro et al. 2010). 
In addition to these controversies, accumulating evidence suggests that the leptin gene is missing in avian species (Friedman-Einat et al. 1999, Pitel et al. 2000, 2009, Amills et al. 2003, Hen et al. 2008, Sharp et al. 2008), stemming from studies based on whole genome and EST sequencing (van Hemert et al. 2003, Burt 2006); genomic mapping (Pitel et al. 2000, 2009, Liu et al. 2007); PCR (Friedman-Einat et al. 1999, Amills et al. 2003); library screening (our unpublished results); Southern, northern, and western analyses (FriedmanEinat et al. 1999, Sharp et al. 2008); and immunohistochemical analyses (Sharp et al. 2008). In addition, adipose tissue gene expression arrays have failed to detect leptin in lean or fat strains of broilers (Wang et al. 2007). Similarly, extensive microarray analysis of chicken fat, liver, and other tissues has failed to identify leptin (Cogburn et al. 2004, 2007, Wang et al. 2007), as has extensive EST screening of fat and other tissues (Cogburn et al. 2003, Carre et al. 2006) and proteomic analysis of abdominal adipose tissues of fat and lean broilers (Wang et al. 2009).

Since much of these data are based on sequence similarity, it was of primary importance to explore the possibility of circulating leptin activity in birds, using the CLEPR-based bioassay, which does not depend on sequence similarities.

One could speculate that exogenous leptins activate CLEPR, despite our inability to identify its natural ligand. This speculation is compatible with the present and previous demonstrations of CLEPR binding to heterologous leptins (Niv-Spector et al. 2005) and its induction by these leptins to activate signal transduction in vitro (Adachi et al. 2008, Hen et al. 2008). However, it is evident that more work is needed to verify the physiological role of CLEPR since the reported physiological responses were obtained with leptin doses much above the physiological concentration of leptins in mammals.

The possibility that the CLEPR may operate through an autocrine or a paracrine circuit cannot be excluded but can neither be supported until the indisputable identification of a chicken leptin.

In summary, our results strongly suggest that in birds, an alternative signaling system to that of the mammalian leptin informs the brain and other tissues of the body's fat stores. Therefore, birds may represent an excellent model system for the study of alternative control mechanisms on appetite and energy metabolism which could be shared by other non-mammalian vertebrates.

\section{Declaration of interest}

The authors declare that there is no conflict of interest that could be perceived as prejudicing the impartiality of the research reported.

\section{Funding}

This work was supported by the Chief Scientist of the Israeli Ministry of Agriculture (grant number 0423 to MFE) and the French Polar Institute Paul Emile Victor (for the penguins' project).

\section{Acknowledgements}

We thank Prof. Stephen O'Rahilly and Prof. Sadaf Farooqi for critically reviewing the manuscript. Contribution number 562/10 from the ARO, the Volcani Center, Bet Dagan, Israel. Godwits were captured with help from Theunis Piersma, Joop Jukema, and the Castricum Ringing Group.

\section{References}

Adachi H, Takemoto Y, Bungo T \& Ohkubo T 2008 Chicken leptin receptor is functional in activating JAK-STAT pathway in vitro. Journal of Endocrinology 197 335-342. (doi:10.1677/JOE-08-0098)

Amills M, Jimenez N, Villalba D, Tor M, Molina E, Cubilo D, Marcos C, Francesch A, Sanchez A \& Estany J 2003 Identification of three single nucleotide polymorphisms in the chicken insulin-like growth factor 1 and 2 genes and their associations with growth and feeding traits. Poultry Science $\mathbf{8 2}$ 1485-1493.

Ashwell CM, Czerwinski SM, Brocht DM \& McMurtry JP 1999a Hormonal regulation of leptin expression in broiler chickens. American Journal of Physiology 276 R226-R232.

Ashwell CM, McMurtry JP, Wang XH, Zhou Y \& Vasilatos-Younken R $1999 b$ Effects of growth hormone and pair-feeding on leptin mRNA expression in liver and adipose tissue. Domestic Animal Endocrinology 17 77-84. (doi:10.1016/S0739-7240(99)00018-1)

Ashwell CM, Richards MP \& McMurtry JP 2001 The ontogeny of leptin mRNA expression in growing broilers and its relationship to metabolic body weight. Domestic Animal Endocrinology 21 161-168. (doi:10.1016/ S0739-7240(01)00113-8)

Baker DM, Larsen DA, Swanson P \& Dickhoff WW 2000 Long-term peripheral treatment of immature coho salmon (Oncorhynchus kisutch) with human leptin has no clear physiologic effect. General and Comparative Endocrinology 118 134-138. (doi:10.1006/gcen.1999.7450)

Benomar Y, Rideau N, Crochet S, Derouet M \& Taouis M 2003 Leptin fully suppresses acetylcholine-induced insulin secretion and is reversed by tolbutamide in isolated perfused chicken pancreas. Hormone and Metabolic Research 35 81-85. (doi:10.1055/s-2003-39055)

Boswell T, Dunn IC, Wilson PW, Joseph N, Burt DW \& Sharp PJ 2006 Identification of a non-mammalian leptin-like gene: characterization and expression in the tiger salamander (Ambystoma tigrinum). General and Comparative Endocrinology 146 157-166. (doi:10.1016/j.ygcen. 2005.08.001)

Bungo T, Shimojo M, Masuda Y, Tachibanab T, Tanaka S, Sugahara K \& Furuse M 1999 Intracerebroventricular administration of mouse leptin does not reduce food intake in the chicken. Brain Research 817 196-198. (doi:10.1016/S0006-8993(98)01223-2)

Burt DW 2006 The chicken genome. Genome Dynamics 2 123-137. (doi:10. 1159/000095100)

Byerly MS, Simon J, Lebihan-Duval E, Duclos MJ, Cogburn LA \& Porter TE 2009 Effects of BDNF, $\mathrm{T}_{3}$, and corticosterone on expression of the hypothalamic obesity gene network in vivo and in vitro. American Journal of Physiology. Regulatory, Integrative and Comparative Physiology 296 R1180-R1189. (doi:10.1152/ajpregu.90813.2008)

Caro JF, Kolaczynski JW, Nyce MR, Ohannesian JP, Opentanova I, Goldman WH, Lynn RB, Zhang PL, Sinha MK \& Considine RV 1996 Decreased cerebrospinal-fluid/serum leptin ratio in obesity: a possible mechanism for leptin resistance. Lancet 348 159-161. (doi:10.1016/ S0140-6736(96)03173-X)

Carre W, Wang X, Porter TE, Nys Y, Tang J, Bernberg E, Morgan R, Burnside J, Aggrey SE, Simon J et al. 2006 Chicken genomics resource: sequencing and annotation of 35,407 ESTs from single and multiple tissue cDNA libraries and CAP3 assembly of a chicken gene index. Physiological Genomics 25 514-524. (doi:10.1152/physiolgenomics.00207.2005)

Cassy S, Derouet M, Crochet S, Dridi S \& Taouis M 2003 Leptin and insulin downregulate leptin receptor gene expression in chicken-derived leghorn male hepatoma cells. Poultry Science 82 1573-1579. 
Cassy S, Picard M, Crochet S, Derouet M, Keisler DH \& Taouis M 2004 Peripheral leptin effect on food intake in young chickens is influenced by age and strain. Domestic Animal Endocrinology 27 51-61. (doi:10.1016/ j.domaniend.2004.01.004)

Chappell MA, Janes DN, Shoemaker VH, Bucher TL \& Maloney SK 1993 Reproductive effort in Adélie penguins. Behavioral Ecology and Sociobiology 33 173-182. (doi:10.1007/BF00216598)

Cogburn LA, Wang X, Carre W, Rejto L, Porter TE, Aggrey SE \& Simon J 2003 Systems-wide chicken DNA microarrays, gene expression profiling, and discovery of functional genes. Poultry Science 82 939-951.

Cogburn LA, Wang X, Carre W, Rejto L, Aggrey SE, Duclos MJ, Simon J \& Porter TE 2004 Functional genomics in chickens: development of integrated-systems microarrays for transcriptional profiling and discovery of regulatory pathways. Comparative and Functional Genomics 5 253-261. (doi:10.1002/cfg.402)

Cogburn LA, Porter TE, Duclos MJ, Simon J, Burgess SC, Zhu JJ, Cheng HH, Dodgson JB \& Burnside J 2007 Functional genomics of the chicken - a model organism. Poultry Science 86 2059-2094.

Concannon P, Levac K, Rawson R, Tennant B \& Bensadoun A 2001 Seasonal changes in serum leptin, food intake, and body weight in photoentrained woodchucks. American Journal of Physiology. Regulatory, Integrative and Comparative Physiology 281 R951-R959.

Crespi EJ \& Denver RJ 2006 Leptin (ob gene) of the South African clawed frog Xenopus laevis. PNAS 103 10092-10097. (doi:10.1073/pnas. 0507519103)

Denbow DM, Meade S, Robertson A, McMurtry JP, Richards M \& Ashwell C 2000 Leptin-induced decrease in food intake in chickens. Physiology and Behavior 69 359-362. (doi:10.1016/S0031-9384(99)00258-9)

Dridi S, Raver N, Gussakovsky EE, Derouet M, Picard M, Gertler A \& Taouis M 2000a Biological activities of recombinant chicken leptin C4S analog compared with unmodified leptins. American Journal of Physiology. Endocrinology and Metabolism 279 E116-E123.

Dridi S, Williams J, Bruggeman V, Onagbesan M, Raver N, Decuypere E, Djiane J, Gertler A \& Taouis M 2000b A chicken leptin-specific radioimmunoassay. Domestic Animal Endocrinology 18 325-335. (doi:10.1016/ S0739-7240(00)00053-9)

Dridi S, Buyse J, Decuypere E \& Taouis M 2005a Potential role of leptin in increase of fatty acid synthase gene expression in chicken liver. Domestic Animal Endocrinology 29 646-660. (doi:10.1016/j.domaniend.2005.05.002)

Dridi S, Swennen Q, Decuypere E \& Buyse J 2005b Mode of leptin action in chicken hypothalamus. Brain Research 1047 214-223. (doi:10.1016/j. brainres.2005.04.034)

Dridi S, Taouis M, Gertler A, Decuypere E \& Buyse J 2007 The regulation of stearoyl-CoA desaturase gene expression is tissue specific in chickens. Journal of Endocrinology 192 229-236. (doi:10.1677/JOE-06-0070)

Dridi S, Temim S, Derouet M, Tesseraud S \& Taouis M 2008 Acute cold- and chronic heat-exposure upregulate hepatic leptin and muscle uncoupling protein (UCP) gene expression in broiler chickens. Journal of Experimental Zoology. Part A, Ecological Genetics and Physiology 309 381-388. (doi:10. 1002/jez.461)

Dunn IC, Boswell T, Friedman-Einat M, Eshdat Y, Burt DW \& Paton IR 2000 Mapping of the leptin receptor gene (LEPR) to chicken chromosome 8. Animal Genetics 31 290. (doi:10.1046/j.1365-2052.2000.00652.x)

Dunn IC, Girishvarma G, Talbot RT, Waddington D, Boswell T \& Sharp PJ 2001 Evidence for low homology between the chicken and mammalian leptin genes. In Avian Endocrinology, pp 327-336. Eds A Dawson \& CM Chaturvedi. New Delhi: Narosa Publishing House.

Farooqi IS \& O'Rahilly S 2009 Leptin: a pivotal regulator of human energy homeostasis. American Journal of Clinical Nutrition 89 980S-984S. (doi:10. 3945/ajcn.2008.26788C)

Farooqi IS, Keogh JM, Kamath S, Jones S, Gibson WT, Trussell R, Jebb SA, Lip GY \& O'Rahilly S 2001 Partial leptin deficiency and human adiposity. Nature 414 34-35. (doi:10.1038/35102112)

Figueiredo D, Gertler A, Cabello G, Decuypere E, Buyse J \& Dridi S 2007 Leptin downregulates heat shock protein-70 (HSP-70) gene expression in chicken liver and hypothalamus. Cell and Tissue Research 329 91-101. (doi:10.1007/s00441-007-0414-6)
Frederich RC, Hamann A, Anderson S, Lollmann B, Lowell BB \& Flier JS 1995 Leptin levels reflect body lipid content in mice: evidence for diet-induced resistance to leptin action. Nature Medicine 1 1311-1314. (doi:10.1038/nm1295-1311)

Friedman JM 2002 The function of leptin in nutrition, weight, and physiology. Nutrition Reviews 60 S1-S14 (discussion S68-84, 85-87). (doi:10.1301/002966402320634878)

Friedman JM 2009 Obesity: causes and control of excess body fat. Nature 459 340-342. (doi:10.1038/459340a)

Friedman-Einat M, Boswell T, Horev G, Girishvarma G, Dunn IC, Talbot RT \& Sharp PJ 1999 The chicken leptin gene: has it been cloned? General and Comparative Endocrinology 115 354-363. (doi:10.1006/gcen.1999.7322)

Friedman-Einat M, Camoin L, Faltin Z, Rosenblum CI, Kaliouta V, Eshdat Y \& Strosberg AD 2003 Serum leptin activity in obese and lean patients. Regulatory Peptides 111 77-82. (doi:10.1016/S0167-0115(02)00259-8)

Heldmaier G, Steinlechner S, Rafael J \& Latteier B 1982 Photoperiod and ambient temperature as environmental cues for seasonal thermogenic adaptation in the Djungarian hamster, Phodopus sungorus. International Journal of Biometeorology 26 339-345. (doi:10.1007/BF02219505)

van Hemert S, Ebbelaar BH, Smits MA \& Rebel JM 2003 Generation of EST and microarray resources for functional genomic studies on chicken intestinal health. Animal Biotechnology 14 133-143. (doi:10.1081/ ABIO-120026483)

Hen G, Yosefi S, Ronin A, Einat P, Rosenblum CI, Denver RJ \& Friedman-Einat M 2008 Monitoring leptin activity using the chicken leptin receptor. Journal of Endocrinology 197 325-333. (doi:10.1677/JOE-08-0065)

Henson MC \& Castracane VD 2006 Leptin in pregnancy: an update. Biology of Reproduction 74 218-229. (doi:10.1095/biolreprod.105.045120)

Horev G, Einat P, Aharoni T, Eshdat Y \& Friedman-Einat M 2000 Molecular cloning and properties of the chicken leptin-receptor (CLEPR) gene. Molecular and Cellular Endocrinology 162 95-106. (doi:10.1016/S03037207(00)00205-7)

Hu Y, Ni Y, Ren L, Dai J \& Zhao R 2008 Leptin is involved in the effects of cysteamine on egg laying of hens, characteristics of eggs, and posthatch growth of broiler offspring. Poultry Science 87 1810-1817. (doi:10.3382/ps. 2008-00040)

Huising MO, Geven EJ, Kruiswijk CP, Nabuurs SB, Stolte EH, Spanings FA, Verburg-van Kemenade BM \& Flik G 2006 Increased leptin expression in common Carp (Cyprinus carpio) after food intake but not after fasting or feeding to satiation. Endocrinology 147 5786-5797. (doi:10.1210/en. 2006-0824)

Jackson AS, Stanforth PR, Gagnon J, Rankinen T, Leon AS, Rao DC, Skinner JS, Bouchard C \& Wilmore JH 2002 The effect of sex, age and race on estimating percentage body fat from body mass index: the Heritage Family Study. International Journal of Obesity and Related Metabolic Disorders 26 789-796. (doi:10.1038/sj.ijo.0802006)

Johnson RM, Johnson TM \& Londraville RL 2000 Evidence for leptin expression in fishes. Journal of Experimental Zoology 286 718-724. (doi:10. 1002/(SICI)1097-010X(20000601)286:7 < 718::AID-JEZ6>3.0.CO;2-I)

Kempf AM, Strother ML, Li C, Kaur H \& Huang TT 2006 Leptin as a marker of body fat and hyperinsulinemia in college students. Journal of American College Health 55 175-180. (doi:10.3200/JACH.55.3.175-180)

Kerry KR, Clarke JR \& Else GD 1993 Identification of sex of Adélie penguins from observations of incubating birds. Wildlife Research 20 725-731. (doi:10.1071/WR 9930725)

Klein S, Coppack SW, Mohamed-Ali V \& Landt M 1996 Adipose tissue leptin production and plasma leptin kinetics in humans. Diabetes 45 984-987. (doi:10.2337/diabetes.45.7.984)

Kling P, Ronnestad I, Stefansson SO, Murashita K, Kurokawa T \& Bjornsson BT 2009 A homologous salmonid leptin radioimmunoassay indicates elevated plasma leptin levels during fasting of rainbow trout. General and Comparative Endocrinology 162 307-312. (doi:10.1016/j. ygcen.2009.04.003)

Kochan Z, Karbowska J \& Meissner W 2006 Leptin is synthesized in the liver and adipose tissue of the dunlin (Calidris alpina). General and Comparative Endocrinology 148 336-339. (doi:10.1016/j.ygcen.2006.04.004)

Krol E, Tups A, Archer ZA, Ross AW, Moar KM, Bell LM, Duncan JS, Mayer C, Morgan PJ, Mercer JG et al. 2007 Altered expression of SOCS3 
in the hypothalamic arcuate nucleus during seasonal body mass changes in the field vole, Microtus agrestis. Journal of Neuroendocrinology 19 83-94. (doi:10.1111/j.1365-2826.2006.01507.x)

Kuo AY, Cline MA, Werner E, Siegel PB \& Denbow DM 2005 Leptin effects on food and water intake in lines of chickens selected for high or low body weight. Physiology and Behavior 84 459-464. (doi:10.1016/j.physbeh. 2005.01.014)

Kurokawa T \& Murashita K 2009 Genomic characterization of multiple leptin genes and a leptin receptor gene in the Japanese medaka, Oryzias latipes. General and Comparative Endocrinology 161 229-237. (doi:10.1016/j.ygcen. 2009.01.008)

Kurokawa T, Murashita K, Suzuki T \& Uji S 2008 Genomic characterization and tissue distribution of leptin receptor and leptin receptor overlapping transcript genes in the pufferfish, Takifugu rubripes. General and Comparative Endocrinology 158 108-114. (doi:10.1016/j.ygcen.2008.06.003)

Ladyman SR, Tups A, Augustine RA, Swahn-Azavedo A, Kokay IC \& Grattan DR 2009 Loss of hypothalamic response to leptin during pregnancy associated with development of melanocortin resistance. Journal of Neuroendocrinology 21 449-456. (doi:10.1111/j.1365-2826.2009. 01862.x)

Landys MM, Piersma T, Guglielmo CG, Jukema J, Ramenofsky M \& Wingfield JC 2005 Metabolic profile of long-distance migratory flight and stopover in a shorebird. Proceedings. Biological Sciences 272 295-302. (doi:10.1098/rspb.2004.2952)

Landys-Ciannelli MM, Ramenofsky M, Piersma T, Jukema J \& Wingfield JC 2002 Baseline and stress-induced plasma corticosterone during longdistance migration in the bar-tailed godwit, Limosa lapponica. Physiological and Biochemical Zoology 75 101-110. (doi:10.1086/338285)

Levine JA, Eberhardt NL \& Jensen MD 1999 Leptin responses to overfeeding: relationship with body fat and nonexercise activity thermogenesis. Journal of Clinical Endocrinology and Metabolism 84 2751-2754. (doi:10.1210/ jc.84.8.2751)

Liu X, Dunn IC, Sharp PJ \& Boswell T 2007 Molecular cloning and tissue distribution of a short form chicken leptin receptor mRNA. Domestic Animal Endocrinology 32 155-166. (doi:10.1016/j.domaniend.2006.02.001)

Lohmus M, Sundstrom LF, El Halawani M \& Silverin B 2003 Leptin depresses food intake in great tits (Parus major). General and Comparative Endocrinology 131 57-61. (doi:10.1016/S0016-6480(02)00643-3)

Lohmus M, Olin M, Sundstrom LF, Troedsson MH, Molitor TW \& El Halawani M 2004 Leptin increases T-cell immune response in birds. General and Comparative Endocrinology 139 245-250. (doi:10.1016/j.ygcen. 2004.09.011)

Lohmus M, Sundstrom LF \& Silverin B 2006 Chronic administration of leptin in Asian Blue Quail. Journal of Experimental Zoology. Part A, Comparative Experimental Biology 305 13-22. (doi:10.1002/jez.a.240)

Londraville RL \& Duvall CS 2002 Murine leptin injections increase intracellular fatty acid-binding protein in green sunfish (Lepomis cyanellus). General and Comparative Endocrinology 129 56-62. (doi:10.1016/S00166480(02)00510-5)

Marikovsky M, Rosenblum CI, Faltin Z \& Friedman-Einat M 2002 Appearance of leptin in wound fluid as a response to injury. Wound Repair and Regeneration 10 302-307. (doi:10.1046/j.1524-475X. 2002.10505.x)

Mauro LJ, Wenzel SJ \& Sindberg GM 2010 Regulation of chick bone growth by leptin and catecholamines. Poultry Science 89 697-708. (doi:10.3382/ ps.2009-00363)

McCaffery BJ \& Gill R 2001 Bar-tailed gowit (Limosa lapponica). The Birds of North America, no. 581. Philadelphia, PA: The Birds of North America Inc.

McMurtry JP, Ashwell CM, Brocht DM \& Caperna TJ 2004 Plasma clearance and tissue distribution of radiolabeled leptin in the chicken. Comparative Biochemistry and Physiology. Part A. Molecular \& Integrative Physiology 138 27-32. (doi:10.1016/j.cbpb.2004.02.017)

Miller DW, Findlay PA, Morrison MA, Raver N \& Adam CL 2002 Seasonal and dose-dependent effects of intracerebroventricular leptin on LH secretion and appetite in sheep. Journal of Endocrinology 175 395-404. (doi:10.1677/joe.0.1750395)
Montez JM, Soukas A, Asilmaz E, Fayzikhodjaeva G, Fantuzzi G \& Friedman JM 2005 Acute leptin deficiency, leptin resistance, and the physiologic response to leptin withdrawal. PNAS 102 2537-2542. (doi:10.1073/pnas.0409530102)

Niv-Spector L, Raver N, Friedman-Einat M, Grosclaude J, Gussakovsky EE, Livnah O \& Gertler A 2005 Mapping leptin-interacting sites in recombinant leptin-binding domain (LBD) subcloned from chicken leptin receptor. Biochemical Journal 390 475-484. (doi:10.1042/BJ20050233)

Nkrumah JD, Keisler DH, Crews DH Jr, Basarab JA, Wang Z, Li C, Price MA, Okine EK \& Moore SS 2007 Genetic and phenotypic relationships of serum leptin concentration with performance, efficiency of gain, and carcass merit of feedlot cattle. Journal of Animal Science 85 2147-2155. (doi:10.2527/ jas.2006-764)

Ohkubo T, Tanaka M \& Nakashima K 2000 Structure and tissue distribution of chicken leptin receptor (cOb-R) mRNA. Biochimica et Biophysica Acta 1491 303-308. (doi:10.1016/S0167-4781(00)00046-4)

Ohkubo T, Nishio M, Tsurudome M, Ito M \& Ito Y 2007 Existence of leptin receptor protein in chicken tissues: isolation of a monoclonal antibody against chicken leptin receptor. General and Comparative Endocrinology 151 269-273. (doi:10.1016/j.ygcen.2007.01.021)

Paczoska-Eliasiewicz HE, Gertler A, Proszkowiec M, Proudman J, Hrabia A, Sechman A, Mika M, Jacek T, Cassy S, Raver N et al. 2003 Attenuation by leptin of the effects of fasting on ovarian function in hens (Gallus domesticus). Reproduction 126 739-751. (doi:10.1530/rep.0.1260739)

Paczoska-Eliasiewicz HE, Proszkowiec-Weglarz M, Proudman J, Jacek T, Mika M, Sechman A, Rzasa J \& Gertler A 2006 Exogenous leptin advances puberty in domestic hen. Domestic Animal Endocrinology 31 211-226. (doi:10.1016/j.domaniend.2005.10.005)

Peyon P, Vega-Rubin de Celis S, Gomez-Requeni P, Zanuy S, Perez-Sanchez J \& Carrillo M 2003 In vitro effect of leptin on somatolactin release in the European sea bass (Dicentrarchus labrax): dependence on the reproductive status and interaction with NPY and GnRH. General and Comparative Endocrinology 132 284-292. (doi:10.1016/S0016-6480(03)00097-2)

Pfundt B, Sauerwein H \& Mielenz M 2009 Leptin mRNA and protein immunoreactivity in adipose tissue and liver of rainbow trout (Oncorhynchus $m y k i s s$ ) and immunohistochemical localization in liver. Anatomia, Histologia, Embryologia 38 406-410. (doi:10.1111/j.1439-0264.2009.00951.x)

Piersma T \& Jukema J 1990 Budgeting the flight of a long-distance migrant: changes in nutrient reserve levels of bar-tailed godwits at successive spring staging sites. Ardea 78 315-338.

Pitel F, Monbrun C, Gellin J \& Vignal A 2000 The chicken LEP (OB) gene has not been mapped. Animal Genetics 31 281. (doi:10.1046/j.1365-2052. 2000.00610.x)

Pitel F, Faraut T, Bruneau G \& Monget P 2009 Is there a leptin gene in the chicken genome? Lessons from phylogenetics, bioinformatics and genomics General and Comparative Endocrinology 167 1-5. (doi:10.1016/j.ygcen.2009. 10.006)

Rao K, Xie J, Yang X, Chen L, Grossmann R \& Zhao R 2009 Maternal low-protein diet programmes offspring growth in association with alterations in yolk leptin deposition and gene expression in yolk-sac membrane, hypothalamus and muscle of developing Langshan chicken embryos. British Journal of Nutrition 102 848-857. (doi:10.1017/S0007114509276434)

Richards MP \& Poch SM 2003 Molecular cloning and expression of the turkey leptin receptor gene. Comparative Biochemistry and Physiology. Part B, Biochemistry and Molecular Biology 136 833-847. (doi:10.1016/S10964959(03)00260-4)

Richards MP, Ashwell CM \& McMurtry JP 1999 Analysis of leptin gene expression in chickens using reverse transcription polymerase chain reaction and capillary electrophoresis with laser-induced fluorescence detection. Journal of Chromatography. A 853 321-335. (doi:10.1016/S00219673(99)00576-2)

Richards MP, Ashwell CM \& McMurtry JP 2000 Quantitative analysis of leptin mRNA using competitive reverse transcription polymerase chain reaction and capillary electrophoresis with laser-induced fluorescence detection. Electrophoresis 21 792-798. (doi:10.1002/(SICI)15222683(20000301)21:4<792::AID-ELPS792> 3.0.CO;2-M)

Ronnestad I, Nilsen TO, Murashita K, Angotzi AR, Gamst Moen AG, Stefansson SO, Kling P, Thrandur Bjornsson B \& Kurokawa T 2010 
Leptin and leptin receptor genes in Atlantic salmon: cloning, phylogeny, tissue distribution and expression correlated to long-term feeding status. General and Comparative Endocrinology 168 55-70. (doi:10.1016/j.ygcen. 2010.04.010)

Rosenblum CI, Vongs A, Tota MR, Varnerin JP, Frazier E, Cully DF, Morsy MA \& Van der Ploeg LH 1998 A rapid, quantitative functional assay for measuring leptin. Molecular and Cellular Endocrinology 143 117-123. (doi:10.1016/S0303-7207(98)00129-4)

Rousseau K, Atcha Z, Cagampang FR, Le Rouzic P, Stirland JA, Ivanov TR, Ebling FJ, Klingenspor M \& Loudon AS 2002 Photoperiodic regulation of leptin resistance in the seasonally breeding Siberian hamster (Phodopus sungorus). Endocrinology 143 3083-3095. (doi:10.1210/en.143.8.3083)

Sagawa MM, Nakadomo F, Honjoh T, Ishioka K \& Saito M 2002 Correlation between plasma leptin concentration and body fat content in dogs. American Journal of Veterinary Research 63 7-10. (doi:10.2460/AJVR.2002.63.7)

Scarpace PJ \& Zhang Y 2009 Leptin resistance: a prediposing factor for diet-induced obesity. American Journal of Physiology. Regulatory, Integrative and Comparative Physiology 296 R493-R500. (doi:10.1152/ ajpregu.90669.2008)

Sempolska K \& Stupnicki R 2007 Relative fat content in young women with normal BMI but differing in the degree of physical activity. Roczniki Państwowego Zakładu Higieny 58 333-338.

Sharp PJ, Dunn IC, Waddington D \& Boswell T 2008 Chicken leptin. General and Comparative Endocrinology 158 2-4. (doi:10.1016/j.ygcen.2008.05.018)

Silverstein JT \& Plisetskaya EM 2000 The effects of NPY and insulin on food intake regulation in fish. American Zoologist 40 296-308. (doi:10.1668/ 0003-1569(2000)040[0296:TEONAI]2.0.CO;2)

Sirotkin AV \& Grossmann R 2007 Leptin directly controls proliferation, apoptosis and secretory activity of cultured chicken ovarian cells. Comparative Biochemistry and Physiology. Part A. Molecular \& Integrative Physiology 148 422-429. (doi:10.1016/j.cbpa.2007.06.001)

Smith J, Al-Amri M, Sniderman A \& Cianflone K 2006 Leptin and adiponectin in relation to body fat percentage, waist to hip ratio and the apoB/apoA1 ratio in Asian Indian and Caucasian men and women. Nutrition and Metabolism 3 18. (doi:10.1186/1743-7075-3-18)

Spanovich S, Niewiarowski PH \& Londraville RL 2006 Seasonal effects on circulating leptin in the lizard Sceloporus undulatus from two populations. Comparative Biochemistry and Physiology. Part B, Biochemistry and Molecular Biology 143 507-513. (doi:10.1016/j.cbpb.2006.01.001)

Staiger H, Tschritter O, Machann J, Thamer C, Fritsche A, Maerker E, Schick F, Haring HU \& Stumvoll M 2003 Relationship of serum adiponectin and leptin concentrations with body fat distribution in humans. Obesity Research 11 368-376. (doi:10.1038/oby.2003.48)

Taouis M, Chen JW, Daviaud C, Dupont J, Derouet M \& Simon J 1998 Cloning the chicken leptin gene. Gene 208 239-242. (doi:10.1016/S03781119(97)00670-7)

Taylor RH 1962 The Adélie penguin Pygoscelis adeliae at Cape Royds. Ibis 104 176-204. (doi:10.1111/j.1474-919X.1962.tb08644.x)

Tomimatsu T, Yamaguchi M, Murakami T, Ogura K, Sakata M, Mitsuda N, Kanzaki T, Kurachi H, Irahara M, Miyake A et al. 1997 Increase of mouse leptin production by adipose tissue after midpregnancy: gestational profile of serum leptin concentration. Biochemical and Biophysical Research Communications 240 213-215. (doi:10.1006/bbrc.1997.7638)

Tups A 2009 Physiological models of leptin resistance. Journal of Neuroendocrinology 21 961-971. (doi:10.1111/j.1365-2826.2009.01916.x)
Tups A, Ellis C, Moar KM, Logie TJ, Adam CL, Mercer JG \& Klingenspor M 2004 Photoperiodic regulation of leptin sensitivity in the Siberian hamster, Phodopus sungorus, is reflected in arcuate nucleus SOCS-3 (suppressor of cytokine signaling) gene expression. Endocrinology 145 1185-1193. (doi:10.1210/en.2003-1382)

Ur E, Grossman A \& Despres JP 1996 Obesity results as a consequence of glucocorticoid induced leptin resistance. Hormone and Metabolic Research $\mathbf{2 8}$ 744-747. (doi:10.1055/s-2007-979891)

Volkoff H 2006 The role of neuropeptide Y, orexins, cocaine and amphetamine-related transcript, cholecystokinin, amylin and leptin in the regulation of feeding in fish. Comparative Biochemistry and Physiology. Part A. Molecular and Integrative Physiology 144 325-331. (doi:10.1016/j.cbpa.2005. 10.026)

Wang JM, Zhang YM \& Wang DH 2006 Seasonal regulations of energetics, serum concentrations of leptin, and uncoupling protein 1 content of brown adipose tissue in root voles (Microtus oeconomus) from the Qinghai-Tibetan plateau. Journal of Comparative Physiology. B 176 663-671. (doi:10.1007/ s00360-006-0089-4)

Wang HB, Li H, Wang QG, Zhang XY, Wang SZ, Wang YX \& Wang XP 2007 Profiling of chicken adipose tissue gene expression by genome array. BMC Genomics 8 193. (doi:10.1186/1471-2164-8-193)

Wang D, Wang N, Li N \& Li H 2009 Identification of differentially expressed proteins in adipose tissue of divergently selected broilers. Poultry Science $\mathbf{8 8}$ 2285-2292. (doi:10.3382/ps.2009-00190)

Yacobovitz M, Solomon G, Gusakovsky EE, Levavi-Sivan B \& Gertler A 2008 Purification and characterization of recombinant pufferfish (Takifugu rubripes) leptin. General and Comparative Endocrinology 156 83-90. (doi:10.1016/j.ygcen.2007.11.013)

Yang SJ \& Denbow DM 2007 Interaction of leptin and nitric oxide on food intake in broilers and Leghorns. Physiology and Behavior 92 651-657. (doi:10.1016/j.physbeh.2007.05.009)

Yang YX, Guo J, Yoon SY, Jin Z, Choi JY, Piao XS, Kim BW, Ohh SJ, Wang MH \& Chae BJ 2009 Early energy and protein reduction: effects on growth, blood profiles and expression of genes related to protein and fat metabolism in broilers. British Poultry Science 50 218-227. (doi:10.1080/ 00071660902736706)

Yuan L, Ni Y, Barth S, Wang Y, Grossmann R \& Zhao R 2009 Layer and broiler chicks exhibit similar hypothalamic expression of orexigenic neuropeptides but distinct expression of genes related to energy homeostasis and obesity. Brain Research 1273 18-28. (doi:10.1016/j.brainres.2009.03.052)

Zhang Y, Proenca R, Maffei M, Barone M, Leopold L \& Friedman JM 1994 Positional cloning of the mouse obese gene and its human homologue. Nature 372 425-432. (doi:10.1038/372425a0)

Zieba DA, Szczesna M, Klocek-Gorka B \& Williams GL 2008 Leptin as a nutritional signal regulating appetite and reproductive processes in seasonally-breeding ruminants. Journal of Physiology and Pharmacology $\mathbf{5 9}$ (Supplement 9) 7-18.

Received in final form 13 July 2010

Accepted 30 July 2010

Made available online as an Accepted Preprint 5 August 2010 